\title{
Money talks: Gender budgeting in the University of Iceland
}

\author{
Finnborg S. Steinpórsdóttir, PhD student, Faculty of Political Science, \\ University of Iceland \\ porgerður Einarsdóttir, Professor, Faculty of Political Science, University \\ of Iceland
}

Thamar M. Heijstra, Assistant Professor, Faculty of Social and Human Sciences, University of Iceland

Gyða Margrét Pétursdóttir, Assistant Professor, Faculty of Political Science, University of Iceland

\begin{abstract}
The article addresses the financial framework, decision-making and budgeting processes of the University of Iceland from a gender perspective. The newly appointed rector of the University of Iceland (elected 2015) together with the university council is currently revising the UI system of the distribution formula of budget allocation. This provides an opportunity to examine the system which is inspired by New Public Management, with emphasis on global competition and performance based indicators. The aim of the article is to scrutinize the current system of budget allocation and distribution and its significance when it comes to gender. We ask how the, allegedly gender neutral, system plays out for different schools and disciplines and for academics in different ranks, when the gender dimension is taken into account. We draw on empirical data collected as part of the GARCIA research project, Gendering the Academy and Research combating Career Instability and Asymmetries, which is supported by the 7th Framework Programme of the European Union. To shed a light on the process we focus on the male-dominated School of Engineering and Natural Sciences (SENS) and the more feminised School of Social Sciences (SSS). The
\end{abstract}




exploration shows that the financial framework, decision-making and budgeting processes at the University of Iceland are rather non-transparent, and biased in favour of the natural sciences. This applies to funding from the state; third party funding; the allocation of funding in the teaching part of the budgeting, as well as the research part. From the article it can be concluded that the current system contains an internal, though unintended, gender bias that needs to be corrected.

Keywords: University of Iceland; gender budgeting; distribution formula; transparency; system of budget allocation.

\section{Introduction ${ }^{1}$}

Since the 1970s, there has been progress in including gender issues in organisational policies, but integrating such issues into practices has proven to be more challenging. We see an opportunity as the newly appointed rector of the University of Iceland (UI), together with the University Council, is currently revising the UI system of the distribution formula of budget allocation (UI 2016a), which resonates well with the UI's Equal Rights Policy 2013-2017 and its emphasis on gender budgeting and fair economic management (UI 2014). This revision is crucial in a period when austerity measures are still prevalent, and global competition, internationalisation, performance orientation and new public management (NPM) tools are more important than ever in the global academic system (Steinpórsdóttir, Heijstra, Einarsdóttir under review). In this regard, NPM has become a global 'reform movement' in which the accountancy and quality control system relies on efficiency, output-driven performance, and the monitoring, assessment and evaluation of professionals (Ward 2012).

Gender is not yet mainstreamed in the UI practices or in the budget decision making (Steinpórsdóttir, Heijstra, Einarsdóttir under review). However, progress is becoming visible as the UI has started a working group that is experimenting with gender budgeting to be able to introduce this on a wider scale in the university. The Council of Europe (2010) defines gender budgeting as "an application of gender mainstreaming in the budgetary process. It means a gender-based assessment of budgets, incorporating a gender perspective at all levels of the budgetary process and restructuring revenues and expenditures in order to promote gender equality."

Altogether, we believe that these two elements - the new rector's revision of the current system and the introduction of gender budgeting in the UI system - provide us with the opportunity to present a more comprehensive understanding of the gender dimensions that Benería, Berik and Floro $(2016,4)$ point out as often lacking in policy measures:

[...] gender mainstreaming in policy and organizational mandates has often resulted in a simplification of gender equality and empowerment goals, [which has] turned a feminist process of social transformation into a technical process to be overseen by bureaucracies and has become] depoliticized. It has produced policy approaches that lack a 


\section{STJÓRNMÁL \& \\ STJÓRNSÝSLA}

comprehensive understanding of the gender dimensions of the issues at hand. This is so particularly when policy measures overlook the range of gender constraints and naively seek to empower women by simply supplying what is perceived as the missing ingredient.

Therefore, this article's objective is to provide insights into the UI's managerial and financial framework and to examine the decision-making and budgeting processes from a gender perspective. Our research question is as follows: What are the characteristics of the current system of budget allocation and distribution at the UI, and what is its significance in terms of gender? By gender, we not only refer to women and men as individuals but also to the gendering of disciplines in terms of power and hierarchies that privilege men and the masculine yet devalue women and the feminine. We are interested in outlining how the budget system plays out in different academic schools and disciplines and for academics in different ranks, when the gender dimension is taken into account.

We draw on empirical data collected as part of the Gendering the Academy and Research combating Career Instability and Asymmetries (GARCIA) research project, which is supported by the $7^{\text {th }}$ Framework Programme of the European Union. This project is concerned with gender equality in European universities and research centres, focusing on the early stages of academic and scientific careers. The Icelandic GARCIA team is responsible for the work package that deals with developing a gender budgeting methodology that can be applied to academic and scientific institutions. This article is the result of that work in the UI.

As the UI is a comprehensive institution comprising five academic schools with 25 faculties, we have selected two academic schools as case examples - the male-dominated School of Engineering and Natural Sciences (SENS) and the more feminised School of Social Sciences (SSS). Before reporting the findings, we first discuss the concept of gender budgeting and the methodology used in the study. The findings are then presented in two phases. The first one outlines how the UI system works in policy and practice, which focuses on the institution's vision and strategies, the financial framework, the system used to allocate funds, and the system of evaluation. The second phase revolves around the gendered effects that are visible within the UI system with regard to the UI landscape, work conditions, research points, third-party funding and matching funds, and research funding. Finally, the conclusion section summarises the overall findings. It emphasises that male-dominated and more feminised disciplines are differently impacted by the current UI policies and processes involving the distribution of funds within the academic institution.

\section{Gender Budgeting}

Gender budgeting emerged from feminist practical politics in Australia in 1984 (Sharp \& Broomhill 2002). It gained international recognition in 1995 when the United Nations' Beijing Platform for Action called for "the integration of [the] gender perspective 
into [the] budgetary decision on policies and programmes" (United Nations 1995). The budget represents the power relations in society. As Budlender points out, "The budget reflects the values of a country - who it values, whose work it values and who it rewards and who and what and whose work it doesn't" (1996, cited in Elson 1999, 11). Furthermore, the budget mirrors gender relations and has different effects on women and men due to their different socioeconomic positioning; it can therefore "(re-)produce gender inequalities and unequal distribution of power between the genders" (Klatzer \& Mader 2008, 2). Gender budgeting is a response to these power and gender relations and is concerned with how a government's actions to raise and allocate funds serve to advance or prevent gender equality. It aims to integrate a gender analysis into economic policy, government spending and revenue proposals. It identifies possibilities for the redistribution of resources to correct imbalances in women's and men's use of, access to and benefits gained from public services (Addabbo, Gunluk-Senesen \& O’Hagan 2015). Gender budgeting can be a form of feminist policy change that aims to "dismantle hierarchies of power that privilege men and the masculine, and the sexual division of labour that devalues women and the feminine" (Htun \& Weldon 2010, cited in O'Hagan 2015 , 235). It also "seeks a more equitable distribution of resources between women and men” (O’Hagan 2015, 235).

Currently found in over 50 countries (Klatzer \& Mader 2008), gender budgeting initiatives have taken various forms and are applied in different settings. These range from the context of international and national feminist movements, such as the UK Women's Budget Group (Himmelweit 2002), to national and sub-national government initiatives, for example, in Austria, where gender budgeting has been legally binding in the constitution since 2009 (Klatzer, Schratzenstaller, Buchinger \& Schaffer 2010), to macroeconomic policies and reform processes, such as the economic governance in the European Union (Klatzer \& Schlager 2015). In Iceland, gender budgeting was one of the methods introduced by the Ministry of Finance to improve public governance, following the global financial crisis of 2008. Gender budgeting has been legally binding in the Act on Public Finances (No. 123/2015) since January 2016. Succeeding the state's initiative, the City of Reykjavík began utilising the gender budgeting tool in 2011 (City of Reykjavík 2014), and the UI has taken up gender budgeting in its policies (UI 2014).

In recent years, gender budgeting has also been studied in individual institutional settings, such as higher education institutions. After Rothe et al.'s (2008) transnational research conducted in Austria, Germany and Poland, the knowledge on how to apply gender budgeting in scientific institutions has increased. In her research, Erbe (2015) discusses public financing of universities and the effect of linking gender equality to two funding tools - the performance-based allocation of funds and the target agreements. Her research in 13 public universities indicates that external pressure, as well as linking the fund allocations to progress in gender equality, increases the academic institutions' willingness to work towards gender equality. Addabbo, Rodríguez-Moroño and GálvezMuños $(2015,196)$ use the capability approach, that is, the "individual's opportunities to 
achieve functioning". They evaluate budgets and policies in two academic institutions in Spain and Italy from the wellbeing and gender budgeting perspectives. They do that by comparing the university's expenditures to how the students rank the capabilities that they consider the academic institution is able to foster their development. Furthermore, Heijstra, Steinpórsdóttir and Einarsdóttir (2016) research on 'academic housework' shows that gender budgeting methods make it possible to explore what academic activities are valued or not valued within the financial system of universities. A key dimension of a budget's impact is the amount of unpaid and often invisible work that needs to be done, which is also an important aspect of discussions on gender equality in academic institutions.

Building on this framework, we intend to illuminate the gender bias in the allocation of public funds within the UI, Iceland's largest academic institution. We do so in our effort to demonstrate the significance of including gender at all levels of the budgetary process. This article contributes to the literature on gender budgeting by adapting the method to the distribution of funds within the academic institution and by focusing on the structural inequalities that result from a gender-blind financial system. Furthermore, the emphasis is on the gendered nature of academic fields, where we acknowledge hierarchies of power within the academic institution that privilege men and the masculine yet devalue women and the feminine. This pilot project is an essential part of developing a gender budgeting methodology that can be applied to European academic and scientific institutions. To our best knowledge, this is a new approach to gender budgeting within academic institutions. Previous research has focused on connecting funding to gender equality incentives (Erbe 2015) and on whether an institution's expenditures are linked to the students' standpoint on their own capabilities (Addabbo, Rodríguez-Moroño \& Gálvez-Muños 2015).

\section{Methodology}

The analysis is based on multiple datasets from 2010 to 2013, collected in the European setting for comparative purposes as part of the GARCIA project. First, we obtained statistical data from the UI website, the UI inner web (Ugla), the UI central administration, the SSS administration and the SENS administration. Second, we gathered data from the Icelandic National Research Fund. The sources of our third dataset comprised five semi-structured interviews with key players working at the central administration, the SSS or the SENS. These fact-finding interviews aimed to acquire data that was not publicly available, as well as to capture the process and ideological underpinnings of the UI's managerial and financial framework. All the data was collected between June 2014 and May 2015. Lasting between 40 and 75 minutes each, the interviews were conducted at the UI. We applied a gender impact assessment (one of the first phases of gender budgeting) on UI policies and practices regarding the male-dominated SENS disciplines and the more feminised SSS disciplines. 


\section{UI system in policy and practice}

\subsection{Governance of the UI: a short overview}

Although the UI has had a long history since its founding in 1911 (for more information, see Hálfdánarson, Matthíasdóttir \& Guðmundsson 2011), our investigation starts in 2008, when the UI and the Iceland University of Education merged, comprising five academic schools with 25 faculties. Currently, the UI operations are covered by the Higher Education Institution Act (No. 63/2006) and the Act on Public Higher Education Institutions (No. 85/2008). The UI offers around 400 programmes to approximately 13,000 registered students, who enter free of charge except for an annual student registration fee.

The UI's governance is in the hands of the University Council and the rector, who serves as the chair of the council and the head of the UI administration (Regulation No. 569/2009). The University Council develops the policies and forms the structural organisation of the UI. The council is also responsible for the general supervision of the operations of the university, schools and institutes and for ensuring that the UI operates in compliance with the legislation and official edicts. The Finance Committee functions under the auspices of the University Council. The UI's director of finance and operations also serves as the head of the Finance Committee; the other committee members are the deans of the academic schools. The director is responsible for the financial control, budgets, accounting, salaries, procurement and scholarship funds (Regulation No. 569/2009). New governance reforms have been NPM inspired, with a strong focus on international rankings, performance-based measurement, accountability and scientific productivity and fundraising (Ward 2012; Veiga, Magalhães \& Amaral 2015). The current evaluation system at the UI is based on this ideology. The deans of the academic schools are in charge of implementing the UI's policies at the school level. They are appointed by the rector for a five-year term and govern day-to-day operations under the rector's mandate (Regulation No. 569/2009). The heads of the 25 faculties are accountable to their respective school deans, and each dean is the faculty head's immediate superior.

\subsection{Ul's vision and strategies}

The UI's overall policy comprises a five-year span. In the 2006-2011 policy, the UI set for itself the goal of becoming one of the top-100 universities ranked in the Shanghai Jiao Tong University list (UI 2006). At that time, the UI did not appear in any of the global university ranking lists. However, led by the rector during that period, it wanted to make the effort in an attempt to attract more governmental financial support by legitimising the position of the university as distinguished from other academic institutions in the Icelandic context (Ársælsson 2011). To reach that goal, researchrelated activities were prioritised. Barely two years later, in 2008, the worldwide financial crisis and accompanying austerity measures and fiscal consolidations made it necessary to downplay the UI's dream of obtaining a top-100 rank. However, shortly before the 


\section{STJÓRNMÁL \& \\ STJÓRNSÝSLA}

2011-2016 policy was publicly presented, it was announced that the UI had reached the 276th place on the Times Higher Education Supplement Ranking List (Góð gjöf á aldarafmæli Háskólans 2011; Times Higher Education n.d.). This achievement kept alive the UI's dream of eventually obtaining a top position. According to recent developments, it had advanced to the 222nd place on the Times' list in April 2016 (UI 2016b).

The UI's 2011-2016 policy not only has the objective of obtaining a position on one of the global academic ranking lists. "Excellence' in its various manifestations has also become the organising principle of the institution's policy, stating that its students and staff are ' $[\ldots]$ determined to strengthen the Icelandic community by achieving excellence in teaching, research, and innovation [...]." The policy contains four subpolicies, of which the first (and therefore presumably the most important one) is on 'research and innovation'. Progress is monitored through key performance indicators, a method indicative of NPM (Ward 2012; Veiga, Magalhães \& Amaral 2015). Hence, the research and innovation sub-policy's performance indicators include the proportion of graduating doctoral and master's-degree students, the annual number of publications, the increase in income from competitive research funds, the number of agreements with domestic and foreign collaborating universities and faculties, the number of patent applications and other exploitation projects, and the number of postdoctoral researchers.

As the second sub-policy, 'teaching and learning' refers to excellence in teaching. Its progress is monitored through key performance indicators, such as the undergraduate graduation rate, the permanent student/full-time teacher ratio, the diversity of teaching methods used, the proportion of satisfied students, the number of UI graduates who enter a top-100 university, to name a few. The third sub-policy, 'human resources', revolves around the welfare of students and teachers. The fourth sub-policy involves 'social and global responsibility', both with key performance measurements, such as the students' satisfaction rates; the proportion of academic employees with PhDs; the number of lectures, symposia and conferences at the UI that are open to the public; and the number of interviews granted and articles written in the mass media by UI employees, reflecting a clear emphasis on NPM tools (Ward 2012; Veiga, Magalhães \& Amaral 2015). The policy underscores concepts such as 'quality', 'increase', 'excellence', 'innovation', 'effort' and 'strength', which reveal and represent the university's aspirations. This is in accordance with the discourse of recent policy documents on higher education in Iceland, in which 'excellence', 'efficiency', 'innovation' and 'competitiveness' are among the most common features (Jóhannesson 2013).

\subsection{Ul's financial framework}

The UI is predominantly financed by public funds, amounting to two-thirds of the institution's funding, which is based on teaching and research agreements between the UI and the government. The institution is additionally supported by third-party funding, comprising research funds and contracts with the business community, students' registration fees and the UI-owned Lottery. The Ministry of Education, Science and Culture estimates the funding for teaching and research, based on the Regulation on 
Appropriations to Universities (No. 646/1999), and agreements with universities, based on the Higher Education Institution Act (No. 63/2006). UI exercises, like other universities in Iceland, full autonomy over its funding; the UI receives one appropriation that the governing body then distributes between teaching and research (Regulation on Appropriations to Universities, No. 646/1999). Table 1 summarizes the funding to the UI, and the allocation within UI and to the academic schools.

Table 1. Summary of the funding to $\mathrm{UI}$ and the allocation within $\mathrm{UI}$ and to the academic schools

\begin{tabular}{|c|c|}
\hline \multicolumn{2}{|c|}{ Funding to UI } \\
\hline $2 / 3$ of the funding is from the state & $1 / 3$ of the funding is third Party funding \\
\hline $2 / 3$ based on teaching agreements: & The University of Iceland Lottery \\
\hline Funds for full-time equivalent students & National Research Funding \\
\hline Contribution for graduated students & International Research Funding \\
\hline $1 / 3$ based on research agreements & Agreements with the business community \\
\hline & Registration fees \\
\hline & Funds for other operations of UI \\
\hline \multicolumn{2}{|c|}{ Allocation of funds within UI } \\
\hline \multicolumn{2}{|l|}{$10 \%$ to UI central administration } \\
\hline \multicolumn{2}{|l|}{$12 \%$ to joint expenses } \\
\hline \multicolumn{2}{|l|}{$10 \%$ to the housing funding model } \\
\hline \multicolumn{2}{|l|}{$68 \%$ to the five academic schools } \\
\hline \multicolumn{2}{|c|}{ Allocation of funds to the academic school (Deililíkan) } \\
\hline \multicolumn{2}{|l|}{ Full-time equivalent students } \\
\hline \multicolumn{2}{|c|}{ Number of graduates with bachelor, master's and PhD degrees } \\
\hline \multicolumn{2}{|l|}{ The academic staff's performance in research } \\
\hline The faculty's success rate in raising third-par & \\
\hline
\end{tabular}

About two-thirds of the state funding is based on a teaching agreement, according to a funding formula (reiknilikan). This formula follows a classification system based on the amount that the institution receives per full-time student (60 ECTS per year), depending on his or her discipline (Table 2). 
Table 2. Price categories for full-time equivalent student by discipline for Icelandic universities for 2016, as applied to UI (excluding e.g., fine arts)

\begin{tabular}{l|c|c}
\hline Price category & Price in thousand ISK & Rate \\
\hline $\begin{array}{l}\text { Social and human sciences, theology, law and comparable } \\
\text { disciplines }\end{array}$ & 644.0 & 1.0 \\
\hline $\begin{array}{l}\text { Computer science, mathematics and comparable } \\
\text { disciplines }\end{array}$ & 1.008 .9 & 1.6 \\
\hline $\begin{array}{l}\text { Education and other comparable disciplines, including } \\
\text { educational practice }\end{array}$ & 969.3 & 1.5 \\
\hline $\begin{array}{l}\text { Nursing and other comparable disciplines, including } \\
\text { clinical work }\end{array}$ & 1.280 .2 & 2.0 \\
\hline $\begin{array}{l}\text { Natural sciences and engineering, including practice and } \\
\text { specialised equipment }\end{array}$ & 1.392 .0 & 2.2 \\
\hline Medicine, including practice and specialised equipment & 1.799 .1 & 2.8 \\
\hline Odontology & 2.806 .6 & 4.4 \\
\hline
\end{tabular}

(The Icelandic State Budget Proposal for 2016) ${ }^{2}$

The number of full-time equivalent students in the forthcoming year is calculated based on the weighted averages of of full-time students in the past two years and the prediction for the current year. For example, the number of full-time students in 2016 is calculated by means of the actual number of students in 2013 (20\% weight), the actual number of students in 2014 (60\% weight) and the prediction on the number of students in 2015 (20\% weight) (The Icelandic State Budget Proposal for 2016). As shown in Table 2 , the state's annual funding for SENS students is $60-100 \%$ higher than that for SSS students. Additionally, the UI receives appropriation for graduated students, as follows: 150.000 ISK per bachelor's-degree student; 50.000 ISK per diploma-degree student; 100.000 ISK per master's or candidate student; and 1.000.000 ISK per doctoral student. The State Budget Proposal neither clarifies the basis for the allocation nor provides any empirical grounds for the price categories. Furthermore, the price categories for several areas (i.e., nursing, computer science and mathematics, natural sciences and engineering, medicine and odontology) have increased in the State Budget Proposal fiscal budget for 2016 to 'strengthen the financial foundation of the university system'. However, the proposal provided no justification for increasing some price categories only (The Icelandic State Budget Proposal for 2016).

The funding and the basis for the appropriation that the UI receives for research follow its agreement with the government, of which the most recent is from June 2011, the UI's centennial fund for 2012-2020. The fund was established to strengthen research and innovation at the UI. Its objective is to reach the Organisation for Economic Cooperation and Development's (OECD) average expenditure per student by 2016, as well as the Nordic countries' average expenditure by 2020. Two-thirds of the funding will be governmental appropriations, and one-third will come from the third-party 
funding obtained by the UI. The fund appropriations will be based on the UI's success in attracting third-party funding (Agreement on Teaching and Research 2012-2016, Appendix 2).

As pointed out earlier, third-party funding for the UI consists of research grants, contracts with the business community, registration fees and funding by means of the UI Lottery. Registration fees are reported in the State Budget Proposal; for 2016, the annual fee is 75.000 ISK per student (The Icelandic State Budget Proposal for 2016). The funds generated from the UI Lottery are used for the construction of buildings since the UI does not obtain state funding for housing. Other third-party funds are allocated to the faculties or the research institutes that obtained the funding. While research projects carried out at the UI receive grants from international and national competitive and non-competitive funds, information on the amounts received by these projects is generally not publicly available. There is also scarce data regarding contracts with the business community ${ }^{3}$, yet this sort of information is key to a thorough gender impact assessment.

\subsection{System of allocating funds within UI}

The UI's Finance Committee distributes the state appropriation within the academic institution. However, third-party funding goes directly to the faculty or the research institute. According to the information retrieved from the administration, the public funding is roughly allocated as follows: $10 \%$ to the UI's central administration, $12 \%$ to joint expenses, $68 \%$ to the five academic schools and $10 \%$ to the housing funding model. The funding for the academic schools and their faculties is allocated according to the following distribution formula (deililikan), where F denotes funding to schools/ faculties (Table 3).

Table 3. Distribution formula (deililikan) for UI schools/faculties

$$
\begin{aligned}
F= & c_{1} \bullet \text { pricecategry } \\
& V_{i} R_{i}+150 B A+550 M S+2.750 N D+40 R S+0,6 E S+ \\
& , 35 I S+0,2 A S \quad H K+\text { Other }
\end{aligned}
$$

\begin{tabular}{l|l}
\hline$c_{1}=$ proportion of teaching funding to schools & $R S=$ no research points \\
\hline$V_{i}=$ active students in category $\mathrm{i}$ & $E S=$ amount of foreign competitive grants \\
\hline$R_{i}=$ price category no $\mathrm{i}$ & $I S=$ amount of domestic competitive grants \\
\hline$M S=$ no graduated $\mathrm{MA} / \mathrm{MS}$ students & $A S=$ amount of other grants \\
\hline$N D=$ no graduated $\mathrm{PhD}$ students & $H K=$ housing costs \\
\hline$B A=$ no graduated $\mathrm{BA} / \mathrm{BS}$ students & \\
\hline
\end{tabular}

(UI n.d.-a)

The formula is based on 'successes' in teaching and research. Allocations in relation to teaching are based on the disciplines of the full-time equivalent students. In the internal 
allocation, the UI follows (to a certain extent) the proportional value of the student price category as presented in the funding formula in Table 2. This means that the UI has its own student price categories for different disciplines that partially resonate with the state's price categories. An interviewee explains that the teaching portion of the whole amount distributed was $64 \%$ of the value in 2013. If a course is inter-disciplinary, then $8 / 10$ of the allocation is given to the faculty that supervises the course, and 2/10 is allotted to the faculty where the student is registered. Faculties can deviate from this rule and make agreements regarding the cost and income for the course. The interviews clearly indicate that the value of the student price category is not set in stone and that the Finance Committee tampers with the distribution formula on an ad hoc basis. Hence, in the last couple of years, the committee has raised the lowest price category by $2-3 \%$ and has moved some disciplines to a higher price category. It is not transparent which disciplines receive this special treatment in the fund allocation, and the information is not publicly available. To reiterate, the availability of this sort of information is crucial for a comprehensive gender impact assessment, thus revealing that the scarcity of information is information in itself. As revealed by table 4 the student body is male dominated in SENS and female dominated in SSS.

Table 4. Students registered in SSS and SENS in 2010-2013 by gender

\begin{tabular}{l|c|c|c|c|c|c}
\hline & \multicolumn{3}{|c|}{ SSS } & \multicolumn{3}{c}{ SENS } \\
\hline & $\begin{array}{c}\text { Total number } \\
\text { of students }\end{array}$ & $\%$ women & $\%$ men & $\begin{array}{c}\text { Total number } \\
\text { of students }\end{array}$ & $\%$ women & $\%$ men \\
\hline 2013 & 4555 & $64.2 \%$ & $35.8 \%$ & 2297 & $39.5 \%$ & $60.5 \%$ \\
\hline 2012 & 4519 & $64.1 \%$ & $35.9 \%$ & 2212 & $38.9 \%$ & $61.1 \%$ \\
\hline 2011 & 4703 & $64.2 \%$ & $35.8 \%$ & 2214 & $39.5 \%$ & $60.5 \%$ \\
\hline 2010 & 4554 & $63.5 \%$ & $36.5 \%$ & 2174 & $39.5 \%$ & $60.5 \%$ \\
\hline
\end{tabular}

Research allocations take the following three elements into account: the number of graduates with $\mathrm{BA}$, master's and $\mathrm{PhD}$ degrees, the academic staff's performance in research and the faculty's success rate in raising third-party funds. First, schools are rewarded 550.000 ISK for a master's-degree graduate and 2.750,000 ISK for a PhD graduate, which are considerably higher than the above-mentioned appropriations from the state. By rewarding research in this way, other aspects receive less funding. According to an interviewee, the Finance Committee tampers with the teaching portion of the distribution formula to make ends meet: 'If we need money, we just lower the proportions of the funding formula that each school gets for teaching'. Second, the academic staff receives research points for their work, for which both the individual and the school are rewarded (in 2014, the amount was 40.000 ISK for each research point; see also the further discussion that follows). Third, schools are financially rewarded for their success in raising third-party funds. The school receives $60 \%$ of the grant value, in so-called matching funds, for international competitive grants, $35 \%$ for national 
competitive grants and $20 \%$ for other grants. The matching funds per faculty have annual limits of 30 million ISK per year. This means that each faculty that secures grants will receive additional funding as a matching fund from the academic institution, which is taken from the government appropriation. Therefore, other faculties that obtain few grants or none at all, especially from international competitive funds, do not receive this financial compensation. Hence, the system creates an unequal distribution of public funds within the UI.

Part of the public funding is labelled 'joint expenses', that is, allocation for research sabbaticals, national access to scholarly articles, the productivity evaluation fund (vinnumatssjódur) for assistant professors and associate professors, and the writing and research fund (ritlauna- og rannsóknarsjófur prófessora), which rewards the work of full professors (see also the next section). Furthermore, about $10 \%$ of the public funding is allocated to the housing funding model (busnadislikean). This model 'encourages more rationalization of the utilization of the housing' (UI 2012, 44). It is not transparent, but according to an interviewee, the model can be called a 'zero-sum game', where one unit's gain is equivalent to another's loss.

\subsubsection{System of evaluation within UI}

The UI's financial system is also influenced by the comprehensive evaluation system for public universities (matskerfi opinberra háskóla). This system forms the basis for the evaluation of the academic staff's work in terms of research, teaching, administration and service. As mentioned earlier, academics are assigned research points for their work, and these points influence their promotion, prestige and salaries. Ten points are rewarded annually to academics with teaching duties. Supervision of postgraduate students is also rewarded, as well as the publication of teaching materials and innovation in teaching. Administrative points are rewarded for administrative work and positions that are under the auspices of the UI or each school as a whole, whereas administrative work under the auspices of faculties is not granted any points (Evaluation System for Public Higher Education Institutions 2013). Additionally, academic staff members who obtain grants from competitive funds are rewarded with research points. Project managers receiving research grants from international competitive funds are awarded double points within an annual limit (Evaluation System for Public Higher Education Institutions 2013). The UI policy for 2011-2016 planned to intensify its managerial interventions so as to increase extramural funding: "Salary and terms of employment will in great measure take into account employees' results in obtaining grants from competitive funds" (UI Policy 2011).

The evaluation of research is based on the publication outlet and special research points, referred to as 'major points' (aflstig). 'Major points' were introduced at the UI in 2010 through the 'incentive and quality assurance system' to 'facilitate the achievement of [the excellence] goals of the policy' and to encourage 'excellent' practices (Agreement on Teaching and Research, 2012-2016, Appendix 1). In this regard, academics need to obtain a certain number of 'major points' to be able to apply for promotion. 


\section{STJÓRNMÁL \& \\ STJÓRNSÝSLA}

Articles published in top-ranked journals in the Thomson Reuters/ISI Web of Science database, with a high-impact factor, as well as books and chapters accepted by the most 'prestigious' publishing houses, are rewarded the most 'major points' (Evaluation system - definition of major points, n.d.). Furthermore, if a paper is published in a 'superior' journal, the author can receive up to double the amount of research points. According to the UI (n.d.-b), these 'superior' journals are Nature, Science, Cell and the New England Journal of Medicine, whose common characteristic is that they mostly publish work from engineering, natural sciences and health sciences.

Moreover, the evaluation system rewards multi-authorship which generates additional points for a publication; there is a strong tradition in the SENS disciplines of doing so. The total number of points associated with a particular work thus becomes a function of the number of authors, up to a certain ceiling. Hence, faculties and research centres receive more points for publications with multiple authors than for single-author articles, which affect their incomes.

As mentioned earlier, the state funding allocated to the UI is mostly based on 'excellence'-related incentives. The UI receives funding for students who finish their courses and earn their degrees but nothing for enrolled students who fail in courses or drop out before completing their studies. The same rule applies to research funding. The agreement between the UI and the Ministry of Education states: "Funding for research is distributed between the academic schools and faculties in accordance to the research points that each unit gains. Hence, little research activity is no longer a private matter of the academic staff member in question, [...] but little activity also reduces the income of the faculty in question" (Agreement on Teaching and Research, 2012-2016, Appendix 1,34). Presumably, this puts pressure on academics who experience the system as unfair and discriminating (Pálsson et al. 2016; UI 2016c).

\subsection{Gendered effect of the UI system}

\subsubsection{Gendered landscape of UI}

Now that we have outlined the UI's overall financial system, it is time to examine how it works in practice, and whether it has gendered consequences. A descriptive analysis of the academic staff reveals the highly gendered academic work within the UI. Vertical segregation is prevalent despite the fact that women have comprised over half of the student population for the last three decades (Ministry of Culture and Education 2002). We refer to the number of academic staff, but information on the full-time equivalent academic staff is comparable and generally shows the same pattern. The UI's full-time academic staff consists of $60 \%$ males and $40 \%$ females, with men occupying $70 \%$ of the full professor positions, $60 \%$ of the associate professor positions and $45 \%$ of the assistant professor positions. In part-time positions, women are over-represented (more than $60 \%$ ) in adjunct and sessional teachers' jobs, which occupy the bottom ranks in the academic hierarchy. It should be noted that adjunct and sessional teachers are not hired on the basis of a qualifications assessment by the school's Evaluation Committee.

To measure the chances of women compared to men attaining a full-professor 
position, a Glass Ceiling Index (GCI) can be calculated. A GCI of 1 indicates that there is no difference between women and men being promoted. A score less than 1 means that men are under-represented in full professor positions, while a score higher than 1 signifies that women are under-represented in full professor positions. "The higher the value, the thicker the glass ceiling" (European Commission Directorate-General for Research 2006, 52). The GCI for the UI was 4.60 in 2013; Table 5 shows that the GCI was 3.11 for the SSS and 6.73 for the SENS in that same year. These scores reveal an apparent glass ceiling at the UI, which is thicker in the SENS than in the SSS, and the difference between the two does not seem to be diminishing.

Table 5. Glass Ceiling Index* for SSS and SENS, 2010-2013

\begin{tabular}{l|l|l|l|l}
\hline & 2010 & 2011 & 2012 & 2013 \\
\hline SSS & 3.08 & 2.95 & 3.04 & 3.11 \\
\hline SENS & 7.46 & 7.14 & 5.56 & 6.73 \\
\hline
\end{tabular}

${ }^{*} \mathrm{GCI}=\mathrm{P} / \mathrm{Pa}$, where $\mathrm{P}=$ proportion of women in grade $\mathrm{A}+\mathrm{B}+\mathrm{C}$ positions, and $\mathrm{Pa}=$ proportion of women in grade $\mathrm{A}$.

The actual numbers of the UI's academic staff in 2013 showed a total of 110 full, associate and assistant professors in the SSS compared to 106 in the SENS. However, the gender composition was more equal in the SSS than in the SENS, with women accounting for $43 \%$ of the academic staff in the SSS and $24 \%$ in the SENS. The majority of the SENS academic staff (65\%) are ranked as full professors compared to $41 \%$ in the SSS. Moreover, the SENS employed 29 academic research specialists/scholars/ scientists, while only two persons (both men) held such positions in the SSS. These are research-oriented positions, and while they include administrative functions in some cases, formal teaching responsibilities are excluded.

As indicated by the GCI, vertical segregation is salient in both the SSS and the SENS, with men occupying higher positions than women. In 2013, men held around $60 \%$ of full professor and associate professor positions and $53 \%$ of assistant professor positions in the SSS. The gender representation was more equal in adjunct positions, and $62 \%$ of the part-time sessional teachers were women. A similar pattern was observed in the SENS, with women under-represented among the academic staff. Men occupied $86 \%$ of full professor positions and around $60 \%$ of associate professor and assistant professor positions. Additionally, $62 \%$ of the academic research specialists/scholars/ scientists were men. The majority of the part-time sessional teachers in the SENS were also men (63\%). However, according to the information from the central administration of the SENS, those positions were mostly held by professionals working outside the UI, contrary to those in the SSS, as discussed below.

Regarding the research-oriented or $\mathrm{PhD}$ student population at the UI, 44\% more $\mathrm{PhD}$ students registered at the SENS than at the SSS, and almost five times more $\mathrm{PhD}$ candidates graduated from the SENS. Men constituted the majority of both $\mathrm{PhD}$ 


\section{STJÓRNMÁL \& \\ STJÓRNSÝSLA}

students (58\%) and $\mathrm{PhD}$ graduates (61\%) in the SENS. In contrast, women accounted for the majority of $\mathrm{PhD}$ students $(72 \%)$ and $\mathrm{PhD}$ graduates $(75 \%)$ in the SSS in 2013.

When we discussed the topic of students with the key players, some of them held strong opinions. Not everyone agreed on how the funding formula (Table 1) distributed funds from the UI to the schools. For instance, some of the interviewees criticised the system for box ticking and 'bean counting'. Others thought that the formula was causing an unfair distribution of public funds. The interviewees were referring to the outcome that the state's annual funding for the SENS students was $65-100 \%$ higher than that for the SSS students.

When examining the annual funding in more detail, it turns out that apart from the Faculty of Economics, most of the SSS faculties are placed in the lowest price category of the state's funding formula, except for the vocational programmes that require practical and professional training or some kind of internship. The only maledominated faculty in the SSS, the Faculty of Economics is the exception since it is the sole SSS faculty accounted for as the mathematics discipline. According to the funding formula, it is then eligible for $60 \%$ higher funding per full-time equivalent student than other SSS disciplines. This has caused discontent in the SSS, reflected, for example, in the resolution on the issue at a meeting in the Faculty of Social and Human Sciences. ${ }^{4}$

\subsubsection{Gendered work conditions}

While the pursuit of an academic career is the most obvious way of showing excellence, the conditions for such an aspiration differ considerably among disciplines. In 2013, the full-time teacher/student ratio at the UI was 1:24. Table 5 shows the difference in this ratio between the SSS and the SENS, for example, 1:43 and 1:21, respectively, in 2013. If the ratio is based on the full-time equivalent students, it becomes lower for both the SSS and the SENS, and the disparity between the schools decreases. According to the information from the central administration, the current full-time equivalent full-time teacher/student ratio is 1:26 in the SSS and 1:16 in the SENS (Guðmundur R. Jónsson, personal communication, 8 June 2016). However, the full-time equivalent students refer only to those who complete their studies, which also forms the basis for the funding to the faculties and the schools. Therefore, this measurement does not consider the total workload in relation to teaching, including the factor of students who fail or drop out. Furthermore, the student dropout rate is known to be higher in the SSS than the SENS (UI 2008). While the difference between these schools can be considered large, it should be noted that in 2010, it was even greater. This can be traced back to being the result of the 2008 financial crisis when the state's expenditures to the UI decreased at the same time as the number of students increased (OECD 2014). Consequently, not only the full-time teacher/student ratio increased at the UI but also its use of temporary employment contracts. 
Table 6. Full-time teacher/student ratio* in SSS and SENS, 2010-2013

\begin{tabular}{l|c|c|c|c|c|c}
\hline \multirow{2}{*}{} & \multicolumn{3}{|c|}{ SSS } & \multicolumn{2}{c}{ SENS } & T/S ratio \\
\cline { 2 - 7 } & $\begin{array}{c}\text { Full-time } \\
\text { teachers (T) }\end{array}$ & Students (S) & T/S ratio & $\begin{array}{c}\text { Full-time } \\
\text { teachers }\end{array}$ & Students & T/S \\
\hline 2013 & 106 & 4555 & $1: 43$ & 110 & 2297 & $1: 21$ \\
\hline 2012 & 100 & 4519 & $1: 45$ & 107 & 2212 & $1: 21$ \\
\hline 2011 & 96 & 4703 & $1: 49$ & 110 & 2214 & $1: 20$ \\
\hline 2010 & 94 & 4554 & $1: 48$ & 118 & 2174 & $1: 18$ \\
\hline
\end{tabular}

*Here, teachers refer to full-time full professors, associate professors and assistant professors.

Between 2008 and 2011, the number of adjuncts increased by 24\%, and the work of part-time sessional teachers, equivalent to full-time adjunct positions, increased by $36 \%$. An interviewee described the situation at the UI as follows:

\begin{abstract}
"We went through the crisis and instead of closing down faculties and units like universities around us had to do, we became dependent on sessional teachers, around 2500 sessional teachers. They are non-unionised and do not have any rights and get little pay, so that's how we solved the financial problems of the university, in short. But we can't have it like this."
\end{abstract}

According to an SSS interviewee, there are two groups of sessional teachers. One group comprises those who make a career out of this kind of job or are waiting for an academic position opportunity. The other group consists of sessional teachers who are experts and hold other occupational positions outside the UI. While both groups are in a precarious position in terms of rights and benefits, paid vacation and sick leave, this is especially the case for the academics of the first group who have made their adjunct or sessional lecturing positions their predominant occupational status and main source of income. As for the unfavourable full-time teacher/student ratio in the SSS and the lack of funding, the school relies heavily on sessional teachers. The information from the SSS administration reveals that the school relies more on the precarious group. In contrast, the SENS depends on experts holding other occupational positions.

\title{
3.5.3 (Gendered) research points
}

As mentioned earlier, the UI evaluation system, the Evaluation System for Public Universities and the 'major points' introduced at the UI in 2010 are more or less SENS oriented. Table 7 presents the number of research points and major points awarded to the academics in the SENS and the SSS. The mean number of research points per academic in the SENS is 27\% higher than that in the SSS, and the mean number of major points per academic staff member in the SENS is 60\% higher than that in the SSS. Such differences could indicate that either the academics in the SENS are more active researchers than their colleagues in the SSS or the evaluation system is more favourable 
to the SENS. There is no currently available analysis that takes gender, academic position and employment period into account when examining research points. However, it would show a more nuanced picture of the research point system. There are strong indications of the system's internal gender bias as men are more numerous in the SENS, which has fewer students. Therefore, the SENS teachers have more time for research, in addition to easier access to research funding, as discussed below.

Table 7. Mean research points and major points in SSS and SENS in 2013

\begin{tabular}{|c|c|c|c|c|c|c|c|c|c|}
\hline \multirow[b]{2}{*}{$\begin{array}{c}\text { Academic } \\
\text { school }\end{array}$} & \multirow[b]{2}{*}{$\begin{array}{c}\text { Number } \\
\text { of staff } \\
\text { members } \\
\text { who } \\
\text { submit the } \\
\text { evaluation } \\
\text { report }\end{array}$} & \multirow[b]{2}{*}{$\begin{array}{l}\text { Equivalent } \\
\text { of a } \\
\text { full-time } \\
\text { position }\end{array}$} & \multicolumn{3}{|c|}{ Research points in 2013} & \multicolumn{3}{|c|}{ Major points in 2013} & \multirow[b]{2}{*}{$\begin{array}{c}\% \text { major } \\
\text { points of } \\
\text { research } \\
\text { points }\end{array}$} \\
\hline & & & $\begin{array}{c}\text { Research } \\
\text { points }\end{array}$ & $\begin{array}{l}\text { Average } \\
\text { number of } \\
\text { research } \\
\text { points/ } \\
\text { number of } \\
\text { academic } \\
\text { staff }\end{array}$ & $\begin{array}{l}\text { Average } \\
\text { number of } \\
\text { research } \\
\text { points/ } \\
\text { equivalent } \\
\text { of a } \\
\text { full-time } \\
\text { position }\end{array}$ & $\begin{array}{l}\text { Major } \\
\text { points }\end{array}$ & $\begin{array}{c}\text { Average } \\
\text { number } \\
\text { of major } \\
\text { points/ } \\
\text { number of } \\
\text { academic } \\
\text { staff }\end{array}$ & $\begin{array}{l}\text { Average } \\
\text { number } \\
\text { of major } \\
\text { points/ } \\
\text { equivalent } \\
\text { of a } \\
\text { full-time } \\
\text { position }\end{array}$ & \\
\hline SSS & 112 & 107,7 & $3.777,0$ & 28,8 & 35,1 & $2.076,2$ & 15,8 & 19,3 & $55 \%$ \\
\hline SENS & 112 & 110,1 & $4.562,7$ & 36,5 & 41,4 & $3.173,4$ & 25,4 & 28,8 & $70 \%$ \\
\hline
\end{tabular}

Research points are based on an evaluation of each publication outlet; the higher the journal's 'impact factor', the more research points are awarded. As shown in Table 7, despite approximately the same number of academic staff members in the SSS and the SENS, there is a considerable difference between their research points. This disparity becomes significant when 'major points' are at stake, with the SENS having $70 \%$ of its research points in this category compared to $55 \%$ for the SSS. Comparing the SSS and the SENS publications in journals ranked on the Thomson Reuters/ISI Web of Science List (not revealed in Table 7) shows that in 2013, the SSS had 39 ISI publications, with $31 \%$ in the ISI's top 20\% journals, in contrast to the SENS' 328 publications, with $60 \%$ in the ISI's top 20\% journals. Again, we suggest that this indicates that in using the Thomson Reuters/ISI Web of Science List and the measurement of the impact factor is biased in favour of the SENS, rather than SENS academics are more active researchers and produce more excellent publications compared to their peers in the SSS ${ }^{5}$. Furthermore, due to the lower full-time teacher/student ratio and greater access to funding, the SENS researchers can use more time and resources to conduct research compared to their SSS colleagues, as described in the following section.

\subsection{4 (Gendered) third-party funding and matching funds}

The SENS receives more third-party funding than SSS does, which affects the faculties' funding. As mentioned earlier, faculties obtain 20-60\% matching funds for grants, with the highest matching funds allocated to grants obtained from international competitive funds. Information on received grants, derived from the European Union's Seventh Framework Programme for 2008-2014, reveals that the SENS received funding for 29 
projects and the SSS did for only six projects. Furthermore, two collaboration SENS and SSS projects received funding. (UI n.d.-d).

At the national level, the Icelandic Research Fund received 236 applications in 2013 and funded nine projects of the SSS and 37 projects of the SENS (The Icelandic Centre for Research n.d.). Table 8 displays the number of funded projects and the average amount granted, by academic school and the principal investigator's gender.

Table 8. Number of research projects funded by the Icelandic Research Fund and the average amount granted, by academic school and principal investigator's gender (2013)

\begin{tabular}{c|c|c}
\hline & $\begin{array}{c}\text { Number of } \\
\text { research projects }\end{array}$ & Average amount \\
\hline SSS & 9 & $\mathbf{6 . 0 1 5 . 7 7 8 ~ I S K ~}$ \\
\hline Men & 5 & 6.151 .400 ISK \\
\hline Women & 4 & 5.846 .250 ISK \\
\hline SENS & 40 & 6.739 .875 ISK \\
\hline Men & 33 & 6.904 .333 ISK \\
\hline Women & 7 & 5.964 .571 ISK \\
\hline Total & 49 & 6.606 .878 ISK \\
\hline
\end{tabular}

(The Icelandic Centre for Research n.d.)

Table 8 shows that the SENS received more funding than the SSS did, and more SENS projects were funded, with higher grant averages. In the SSS, the principal investigator was a man in five projects and a woman in four projects, with the average amount granted higher for men than for women. In the SENS, the principal investigator was a man in $82,5 \%$ of the projects and a woman in $17,5 \%$ of the projects, but the average amount granted was higher for women than for men.

Not only is the extramural funding much higher for the SENS than the SSS, but this funding also directs the distribution of public resources to scholars and faculties through the incentive system in terms of matching funds (as previously mentioned). This adds to the bias in the system, as already explained. There are more male academic staff members in the SENS, which has fewer students. This means a more favourable full-time teacher/student ratio and consequently, higher quality teaching for the students, who comprise a higher proportion of males than females. This school's easier access to funding also means more opportunities and time for research and hence for publication. Moreover, the UI system of matching funding rewards those who are already successful in obtaining funding; funding begets funding.

\subsubsection{Gendered research funding within UI: The UI Research Fund}

Apart from third-party funding, academics have the opportunity to seek research funding within the UI. In 2013, the UI Research Fund received 254 applications, 56.7\% from 
Finnborg S. Steinpórsdóttir, Porgerđur

Einarsdóttir, Thamar M. Heijstra,

Gyđa Margrét Pétursdóttir
STJÓRNMÁL

STJÓRNSÝSLA

men and $43.3 \%$ from women. In total, 229 academics received funding, comprising $58.5 \%$ men and $41.5 \%$ women. The success rates were $93.0 \%$ for men and $86.4 \%$ for women (UI n.d.-c).

Table 9 reveals the number of internally funded research projects in the SSS and the SENS by academic position and gender and the amount of funding in 2013. For every SSS project funded, the SENS had almost three projects funded. The success rate of SENS academics (96\%) was higher than that of their SSS colleagues $(84 \%)$. The SENS received $26 \%$ higher funding on average for its research projects, with the average amount of 1,162,824 ISK compared to 921,154 ISK for the SSS projects. In the SSS, an equal number of men and women received funding; the success rate was higher for women but men obtained slightly more funding even though women applied for $10 \%$ higher funding on average than men did. In the SENS, $77 \%$ of the funded research projects were led by men, who had a higher success rate and received $14 \%$ higher funding on average than women did although women applied for 13\% higher funding on average than men did. Interestingly, these findings indicate that women apply for higher funding than men do but receive less than men.

Table 9. UI Research Fund 2013: Number of funded research projects by academic position, principal investigator's gender, amount of funding granted and men's and women's success rates

\begin{tabular}{|c|c|c|c|c|c|c|c|c|}
\hline & \multicolumn{6}{|c|}{ Funded projects } & \multicolumn{2}{|c|}{ Success rate } \\
\hline & \multicolumn{2}{|c|}{$\mathbf{N}$} & \multicolumn{2}{|c|}{$\begin{array}{l}\text { Amount funded } \\
\text { in thousand ISK }\end{array}$} & \multirow[t]{2}{*}{ Total N } & \multirow{2}{*}{$\begin{array}{c}\text { Total } \\
\text { amount } \\
\text { funded in } \\
\text { thousand } \\
\text { ISK }\end{array}$} & \multirow[b]{2}{*}{ Men } & \multirow[b]{2}{*}{ Women } \\
\hline & Men & Women & Men & Women & & & & \\
\hline SSS & 13 & 13 & 12.100 & 11.850 & 26 & 23.950 & 0.81 & 0.87 \\
\hline Adjunct & & & & & & & & 0.00 \\
\hline Assistant professor & 3 & 3 & 1.600 & 2.300 & 6 & 3.900 & 0.75 & 0.75 \\
\hline Associate professor & 2 & 1 & 1.500 & 800 & 3 & 2.300 & 0.67 & 1.00 \\
\hline Full professor & 8 & 9 & 9.000 & 8.750 & 17 & 17.750 & 0.89 & 1.00 \\
\hline SENS & 57 & 17 & 68.249 & 17.800 & 74 & 86.049 & 0.97 & 0.94 \\
\hline Assistant professor & 3 & 1 & 3.700 & 1.100 & 4 & 4.800 & 1.00 & 0.50 \\
\hline Associate professor & 5 & 6 & 5.300 & 5.100 & 11 & 10.400 & 1.00 & 1.00 \\
\hline Full professor & 34 & 6 & 41.449 & 7.800 & 40 & 49.249 & 0.97 & 1.00 \\
\hline Research specialist & 3 & 1 & 2.400 & 1.100 & 4 & 3.500 & 1.00 & 1.00 \\
\hline Research scholar & 2 & & 1.900 & & 2 & 1.900 & 0.67 & \\
\hline Research scientist & 10 & 3 & 13.500 & 2.700 & 13 & 16.200 & 1.00 & 1.00 \\
\hline
\end{tabular}

(UI n.d.-c) 
Since the evaluation of an application is primarily based on the applicant's research activity, academics in higher positions will more likely secure funding. If the number of applicants in relation to the applicant pool is taken into account, the SSS women comprise a higher proportion than their male colleagues who send applications to the UI Research Fund. Overall, the opposite case is observed in the SENS.

\section{Conclusion}

This article has aimed to outline the UI's managerial and financial framework in order to provide better insights into a complicated and at times opaque budgeting system, while examining the decision-making and budgeting processes from a gender perspective. Gender budgeting can be a form of feminist policy change that aims to "dismantle hierarchies of power that privilege men and the masculine, and the sexual division of labour that devalues women and the feminine" (Htun \& Weldon 2010, cited in O'Hagan 2015, 235). The findings reveal that the corporate instruments used at the UI are more favourable for the male-dominated SENS than for the more feminised SSS. Although the instruments are generally perceived as objective and gender neutral, we have found evidence that by rewarding male-dominated fields, the current system increases indirect gender discrimination in academia.

In terms of research, the UI encourages faculties to engage in research-related activities. Depending on their performance, the faculties receive additional allocation, which is taken from the government appropriation. With the public funding being a 'zerosum game', the university tampers with the teaching portion of the distribution formula to make ends meet. Therefore, the financial compensation for these rewarded research activities affects the allocation for other activities, such as teaching. More teachingoriented faculties are thus denied this financial compensation based on these criteria. All allocations to the faculties that are intended for research-related activities give the SENS faculties more advantage than the SSS faculties. The assessment of the academic staff's research performance is built on the SENS' focused criteria and traditions, such as the amount of obtained international competitive funding, publications in international 'excellent' and 'superior' journals and multi-authorship in publications. Moreover, the faculty's success in raising third-party funds and the matching funds are more beneficial to the SENS than to the SSS since the former has significantly more projects funded than the latter.

As for teaching, the state's funding formula for it rewards almost $60-100 \%$ higher funding to the academic institution for full-time equivalent SENS students than for fulltime equivalent SSS students. When allocating funds to the academic schools, the UI keeps the same proportions for the academic fields, to a certain extent. The SSS has a significantly higher number of students than the SENS, but according to the information from the administration, low funding per full-time equivalent student makes it difficult for the school to hire full-time academic staff. This becomes apparent in the full-time teacher/student ratio, which is almost double in the SSS compared to the SENS.

Not only does this system have different effects on the academic fields and the 
distribution of funds, but it also directly influences the individual academics working in the SSS and the SENS. The research points, especially the major points, affect the academics' opportunities for promotion, prestige and salaries. The SENS academics earn on average $27 \%$ more research points than their SSS colleagues, and the average number of major points per academic staff member in the SENS is $60 \%$ higher than in the SSS. This disparity could explain why the academic staff members of the SENS occupy higher positions than their SSS peers. This difference indicates that the academics in the SENS are either more active researchers than their SSS counterparts or that the evaluation system is more favourable to the SENS. The evaluation system acknowledges research activities but undervalues teaching and the heavy workload that academics have to manage, especially in the SSS faculties, which have the highest full-time teacher/ student ratio. Furthermore, research activities and academics' positions determine the academics' chances of funding. With these as factors for success in securing funding, the grant distribution system turns out to be SENS and male focused. The majority of the research points and major points are earned by the SENS, and with vertical segregation prevailing in both academic schools, most of the academics who hold full-professor positions are men.

By applying the gender impact analysis, which is one of the first phases of gender budgeting, and critically evaluating the UI's financial framework, we have demonstrated that male-dominated and more feminised disciplines are impacted differently by the policies and processes of fund distribution in the academic institutions. This analysis reveals that resources are not distributed in a gender-equitable way. It simultaneously creates an opportunity to readdress the inequity and revise academic budgetary policies and resource distribution in order to ensure fairer and equal academia. However, to attain its full potential, the UI needs to go beyond the step of analysing data and processes and discuss the possible gender consequences when revising the system, for which the rector and the academic council are currently preparing. The UI should start incorporating a gender perspective at all levels of the budgetary process and restructure the current system used in fund distribution to promote gender equality. We agree with Benería, Berik and Floro (2016) that it is insufficient to simply provide the missing ingredient; to attain gender equality at the UI, the structure of the funding system needs to be changed.

\section{Notes}

1 The research leading to these results has received funding from the European Union's Seventh Framework Programme (FP7/2007-2013) under grant agreement nº11737.

2 Two deductions are made from the amount in the funding formula, according to the Icelandic State Budget Proposal for 2016: first, the revenue from the registration fees and second, the calculated investment in the state's housing that the public universities make use of.

3 Yet another third party funding source are tuition fees for the Continuing Education which go directly to that program as it is self-financed and does not receive additional funding from UI.

4 The issue was discussed at a faculty meeting in the Faculty of Social and Human Sciences, February 5, 2016. Resulting in a resolution by the faculty to the decision making bodies to equalise the funding to the Faculty in accordance with the funding to the Faculty of Economics. 
5 Journal rankings and citation indices has received criticism for its limitations (see for instance Seglen 1997, Jamal et al. 2008). It would be interesting to analyse the UI data from that perspective, that however, is not the subject of this article.

\section{References}

Act on Public Finances, No. 123/2015. (Icel.).

Act on Public Higher Education Institutions, No. 85/2008. (Icel.).

Addabbo T., Gunluk-Senesen, G. and O'Hagan, A. (2015). "Gender Budgeting: Insights from current methodologies and experiences in Europe", Politica Economica / Journal of Economic Policy 31(2), 125134.

Addabbo T., Rodríguez-Moroño, P. and Gálvez-Muños, L. (2015). "Gender budgeting in education from a wellbeing approach: An application to Italy and Spain", Politica Economica / Journal of Economic Policy 31(2), 195-212.

Agreement on teaching and research between University of Iceland and the Ministry of Education, Research and Culture 2012 - 2016, Appendix 1. (Icel.).

Agreement on teaching and research between University of Iceland and the Ministry of Education, Research and Culture 2012 - 2016, Appendix 2. (Icel.).

Ársælsson, K. M. (2011). Academic Apartheid. A Case Study: Organizational Perspective on the Academic Field in Iceland. (Unpublished master's thesis). University of Iceland, Reykjavík.

Benería, L., Berik, G. and Floro, M. (2016). Gender, development and globalization. New York: Routledge Taylor \& Francis Group.

Council of Europe. (2010). Parliamentary Assembly: Recommendation 1921 (2010).

Elson, D. (1999). Gender Budget Initiative. Background Paper. London: Commonwealth Secretariat.

Erbe, B. (2015). "Gender Mainstreaming in Public Financing of Universities: Central Findings for Germany", Politica economica - Journal of Economic Policy 31(2), 213-232.

European Commission, Directorate-General for Research. (2006). She Figures 2006. Women and Science. Statistics and Indicators. Luxembourg: Office for Official Publications of the European Communities.

Evaluation system - definition of major points. (n.d.) Retrieved from Ugla - the inner web of University of Iceland.

Evaluation System for Public Higher Education Institutions. (2013). Retrieved from: http://www.hi.is/ sites/default/files/admin/meginmal/skjol/evaluation_system_for_public_higher_education_ institutions.pdf. (Icel.).

„Góð gjöf á aldarafmæli Háskólans“. (2011, 7 October). Morgunblađið, 7.

Hálfdánarson, G., Matthíasdóttir, S. and Guðmundsson, M. (2011). Aldarsaga Háskóla Íslands 1911-2011, in G. Karlsson (ed.). Reykjavík: Háskólaútgáfan.

Heijstra, T. M., Steinpórsdóttir, F. S. and Einarsdóttir, D. (2016). "Academic career making and the double-edged role of academic housework", Gender \& Education [published online; doi: 10.1080/09540253.2016.1171825].

Higher Education Institution Act, No. 63/2006. (Icel.).

Himmelweit, S. (2002). "Making visible the hidden economy: The case for gender-impact analysis of economic policy", Feminist Economics 8(1), 49-70.

Jamal, T., Smith, B. and Watson, E. (2008). "Ranking, rating and scoring of tourism journals: Interdisciplinary challenges and innovations", Tourism Management 28, 66-78.

Jóhannesson, I. Á. (2013). "Excellence, Innovation and Academic Freedom in University Policy in Iceland", Stjórnmál og Stjórnsýsla 9(1), 79.

Klatzer, E., and Schlager, C. (2015). "The Big Picture Makes a Big Difference: Taking into Account Changed Framework Conditions for Budgetary Policies at European Level in Gender Responsive Budgeting", Politica Economica / Journal of Economic Policy 31(2), 135-154.

Klatzer, E., Schratzenstaller, M., Buchinger, B., and Schaffer, N. (2010). "Gender Budgeting in the 


\section{STJÓRNMÁL \& STJÓRNSÝSLA}

Constitution-A Look at Formal and Real Conditions in Austria", Internationale Politik und Gesellschaft 2, 48-64.

Klatzer, E. and Mader, K. (2008, January). "Expanding the Theoretical Foundations and Methodological Approach of Gender Budgeting: Feminist Democratic Implications". Paper presented the International Conference on Gender Responsive Budgeting and Social Justice, Vilnius, Lithuania, Jan 10-11, 2008.

Ministry of Culture and Education. (2002). Konur i vísindum [Women in science]. Reykjavík: Ministry of Culture and Education.

OECD. (2014). Education at a Glance 2014: OECD Indicators. OECD Publishing.

O'Hagan, A. (2015). "Favourable conditions for the adoption and implementation of gender budgeting: Insights from comparative analysis", Politica economica - Journal of Economic Policy 31(2), 233-252.

Pálsson, A., et al. (2016, 10 February). "Kerfisbundinn launamunur fræðagreina og kynja við opinbera háskóla" [Systematic wage difference between disciplines and gender at public universities] Fréttabladid, 15.

Regulation for the University of Iceland no. 569/2009. (Icel.).

Regulation on Appropriations to Universities no. 646/1999 (Icel.).

Rothe, A., Erbe, B., Fröhlich, W., Klatzer, E., Lapniewska, Z., Mayrhofer, M. and Debski, M. (2008). Gender Budgeting as a Management Strategy for Gender Equality at Universities: Concluding Project Report (F. Munchen, Trans.) ISBN-13:978-3-937120-09-6. Munich, Germany.

Seglen, P. O. (1997). "Why the impact factor of journals should not be used for evaluating research", BMJ: British Medical Journal 314, 498-502.

Sharp, R. and Broomhill, R. (2002). "Budgeting for equality: The Australian experience", Feminist economics 8(1), 25-47.

Steinpórsdóttir, F. S., Heijstra, T. M. and Einarsdóttir, P. (under review). “The making of the 'excellent' university: A drawback for gender equality“.

The 2016 Icelandic State Budget Proposal (Icel.).

The City of Reykjavík (2014). Handbók um kynjaða fjárbags- og starfsáatlun [Handbook on gender budgeting] Retrieved from: http://reykjavik.is/sites/default/files/handbok_kynjadrar_fjarhags-_ og_starfsaaetlunar.pdf.

The Icelandic Centre for Research (n.d.). Úthlutanir úr rannsóknar- og nýsköpunarsjóðum [Allocation from research and innovation funds]. Retrieved from http://rannis.rhi.hi.is/AllocatedFunds/all. php.

Times Higher Education. (n.d.). World University Rankings 2011-2012. Retrieved from https://www. timeshighereducation.com/world-university-rankings/2012/world-ranking\#!/page/0/length/25.

United Nations. (1995). Fourth World Conference on Women: Platform of Action and the Beijing Declaration. New York: UN Department of Public Informationp

University of Iceland. (2016a, 4 February). Háskólaráðsfundur 4. febrúar 2016 [University Council Minutes, February 4, 2016]. Retrieved from: http://www.hi.is/adalvefur/haskolaradsfundur_4_ februar_2016.

University of Iceland. (2016b, 12 April). HÍ upp um nær 50 sæti á lista yfir bestu háskóla heims [UI up almost 50 seats on a list of best universities in the world]. Retrieved from: http://www.hi.is/ frettir/ hi_upp_um_naer_50_saeti_a_lista_yfir_bestu_haskola_heims.

University of Iceland. (2016c, n.d.). Vinnumat á villigötum? Háskólakennarar á tímum nýfrjálshyggju [Work evaluation on the wrong track? University teachers during neo-liberal times] http://www. hi.is/vidburdir/vinnumat_a_villigotum_haskolakennarar_a_timum_nyfrjalshyggju.

University of Iceland. (2014). University of Iceland Equal Rights Policy 2013-2017. Retrieved from: http://english.hi.is/university/equal_rights_policy.

University of Iceland. (2012). University of Iceland Yearbook 2010. Reykjavík: Háskóli Íslands.

University of Iceland. (2011). Policy of the University of Iceland 2011 - 2016. Retrieved from: http:// english.hi.is/files/afmaeliforsida/policy_2011-2016.pdf. 
University of Iceland. (2008). Skýrsla nefndar um inntöku nýnema og aðgerðir gegn brottfalli úr námi. [Report of the committee on the admission of new students and measures against student's drop out]. (Unpublished report).

University of Iceland. (2006). Policy of the University of Iceland 2006-2011. Retrieved from: http:// english.hi.is/files/bryndjo/policy_of_the_university_of_iceland_2006.pdf.

University of Iceland. (n.d.-a). Deililíkan fyrir útdeilingu fjár til sviða/deilda [Distribution formula of funding to schools/faculties].

University of Iceland. (n.d.-b). Mat á greinum úr framúrskarandi tímaritum [Evaluation of articles in superior journals]. Retrieved from http://ugla.hi.is [University of Iceland' intranet].

University of Iceland. (n.d.-c). Rannsóknasjóður 2013 [Research fund 2013]. (Unpublished document from the University's central administration).

University of Iceland. (n.d.-d). Verkefni innan HÍ sem hafa hlotið styrk úr 7RÁ [Projects within UI that have received FP7 funding]. Retrieved from: http://www.hi.is/sites/default/files/admin/ meginmal/skjol/Yfirlit\%20verkefna\%2022.9.2014.pdf.

Veiga, A. Magalhães, A. and Amaral, A. (2015). "From collegial governance to boardism: Reconfiguring governance in higher education", in M. Souto-Otero, J. Huisman, D.D. Dill, H. de Boer, A.S. Oberai, and L. Williams (eds.), The Palgrave International Handbook of Higher Education Policy and Governance, 398.

Ward, S., C. (2012). Neoliberalism and the Global Restructuring of Knowledge and Education. New York: Routledge. 